\title{
CONNEXIN 43 EXPRESSION IN THE HUMAN COCHLEA: AN IMMUNOHISTOCHEMISTRY STUDY
}

\author{
Wei Liu, Marja Bostrom, Anders Kinnefors, Fredrik Edin, Helge Rask-Andersen \\ Department of Otolaryngology, Uppsala University Hospital, Uppsala, Sweden \\ Corresponding author: Helge Rask-Andersen and Wei Liu, Department of Surgical Sciences, Section \\ of Otolaryngology, Uppsala University Hospital, SE-751 85 Uppsala, Sweden, Phone: +46-18-6115456, \\ e-mail: helge.rask-andersen@akademiska.se (H. Rask-Andersen) and lwoo24@gmail.com (Wei Liu)
}

\begin{abstract}
Background: Mutations in the gene GJA1 which encodes gap junction protein connexin 43 (Cx43) have been linked to nonsyndromic prelingual deafness in humans. The protein forms gap junction channels (GJChs), creating intercellular pathways for ions and small molecules - such as second messengers (IP3, cAMP, cGMP, and others), diverse metabolites (e.g. glucose, amino acids, glutathione, ATP) and neuroprotectant (e.g. adenosine) - to reach neighboring cells. Cx43 in glial cells of the central nervous system (CNS) and in satellite glial cells of the peripheral nociceptive sensory ganglia has been studied for its structure as well as function in signal transduction and neuron protection. Distribution of $\mathrm{Cx} 43$ in the human cochlea is an important unresolved issue.
\end{abstract}

Material and methods: For the first time we analysed, using immunofluorescence and confocal immunofluorescence, the expression and distribution of $\mathrm{Cx} 43$ in 5 normal fresh human cochleae obtained at surgery for removal of giant posterior cranial fossa meningioma.

Results: In the lateral wall of the cochlea, $\mathrm{Cx} 43$ was expressed mainly in the basal cell layer of the stria vascularis and the fibrocytes of the spiral ligament. In the organ of Corti, $\mathrm{Cx} 43$ antibody strongly stained both inner and outer pillar cells, the covering layer cells of the basilar membrane and the supporting cells underneath outer hair cells. In the spiral ganglion, Cx43 expression was located in the satellite glial cells (SGCs) surrounding type I neurons.

Conclusions: Cx43 expression was found in human cochleae including the lateral wall, organ of Corti and spiral ganglion satellite cells. Potential roles played by GJChs built up by $\mathrm{Cx} 43$ in maintaining homeostasis of the cochlea and protection of neurons are speculated.

Key words: human cochlea $\bullet$ Connexin $43 \bullet$ immunohistochemistry • spiral ganglion $\bullet$ satellite glial cells

\section{ЭКСПРЕССИЯ КОННЕКСИНА 43 В УЛИТКЕ УХА ЧЕЛОВЕКА - ИММУНОГИСТОХИМИЧЕСКОЕ ИССЛЕДОВАНИЕ}

\section{Резюме}

Введение: Мутации в гене GJA1, который кодирует белок щелевого соединения коннексина 43 (Сх43), были связаны с несиндромной доречевой глухотой человека. Белок формирует канал щелевого соединения (GJCh), который составляет межклеточные проходы для ионов и маленьких молекул, таких как вторичные посредники (Инозитолтрифосфат IP3, Циклический аденозинмонофосфат (цАМФ), Циклический гуанозинмонофосфат (цГМФ) и другие), разнообразные метаболиты (например, глюкоза, аминокислоты, глутатион, аденозинтрифосфат) и нейропротектанты (например, аденозин), чтобы пройти и достигнуть соседние клетки. Сх43 в глиальных клетках центральной нервной системы (ЦНС) и в глиальных клетках-спутниках периферической нервной системы ганглия был исследован на основе его структуры, так же как и функции трансдукции сигнала и защиты нейрона. Распределение Сх43 в улитке уха человека является важной проблемой, которая должна быть исследована.

\footnotetext{
Материалы и методы: Первыми в мире мы проанализировали, используя иммунофлюоресценцию (метод флуоресцирующих антител) и конфокальную иммунофлюоресценцию, экспрессию и распределение Сх43 в пяти нормальных новых человеческих улитках, полученных во время операции удаления гигантской менингиомы задней части черепа.
}

Результаты: В боковой стенке улитки уха Сх43 был выражен, главным образом, в нижнем клеточном слое полоски нефрита васкулярного и фиброцитов спиральной связки. В органе Корти, антитело Сх43 сильно закрасило внутренние и внешние клетки столба, покрывая слой клеток основной мембраны и клетки поддержки под 
внешними волосковыми клетками. В спиральном нервном ганглиеме экспрессия Сх43 была расположена в глиальных клетках-спутниках, окружающих нейроны первого типа.

Итоги: Экспрессия Сх43 была найдена в улитке уха человека включая боковую стенку, орган Корти и спиральные клетки-спутники нервного узла. Особое вниманеи заслуживают потенциальные роли, которые играли GJCh, созданные Сх43 для поддержания гомеостаза улитки уха и защиты нейронов.

Ключевые слова: Улитка уха человека • Коннексин 43 • Иммуногистохимическое исследование • спиральный нервный узел • глиальные клетки-спутники

\title{
EXPRESIÓN DE CONNEXIN 43 EN CÓCLEA HUMANA - UN ESTUDIO INMUNOHISTOQUÍMICO
}

\begin{abstract}
o
Extracto: Las mutaciones en el gene GJA1 que codifica el connexin 43 de proteínas de unión de hueco (Cx43) han sido unidas a la sordera prelingual no sindrómica del humano. La proteína forma el canal de unión de hueco (GJCh) que constituye caminos intercelulares para iones y pequeñas moléculas, como segundos mensajeros (IP3, CAMPO, cGMP, y otros), metabolites diversos (por ejemplo, glucosa, aminoácidos, glutatión, ATP) y neuroprotector (por ejemplo, adenosina) para pasar y alcanzar células en las células vecinas. Cx43 en células gliales en el sistema nervioso central (SNC) y en las células satélite gliales del ganglia sensorial nociceptivo periférico ha sido estudiado en su estructura así como en su función en transducción de señal y protección de neurona. La distribución de Cx43 en la cóclea humana es el problema importante que debería ser estudiada.
\end{abstract}

Material y métodos: Por primera vez por todo el mundo analizamos, usando inmunofluorescencia y inmunofluorescencia confocal, la expresión y la distribución de Cx43 en cinco cocleas humanos frescos normales obtenidos en una cirugia del retiro de las meningiomas de la gigantesca fosa craneal posterior.

Resutls: En la pared lateral de la cóclea, Cx43 fue expresado principalmente en la capa de célula básica de la estría vascular y los fibrocitos del ligamento espiral. En el órgano de Corti, anticuerpo de Cx43 fuertemente mancharon células de pilar tanto interiores como externas, cubriendo la capa de células de la membrana basilar y las células de apoyo debajo de células de pelo externas. En el ganglio espiral, la expresión de Cx43 estaba localizada en las células satélite gliales (CSGs) circundantes a los neuronas de tipo I.

La expresión de conclusion: $\mathrm{Cx} 43$ fue encontrada en la cóclea humana incluso pared lateral, órgano de Corti y células satélite de ganglio espiral. Son especulados los papeles potenciales desempeñados por GJChs aumentado por Cx 43 en el mantenimiento de homeostasis de la cóclea y la protección de las neuronas.

Palabras claves: cóclea de humano • Connexin 43 • estudio inmunohistoquímico • ganglio espiral • células satélite gliales

\section{Background}

Some 21 connexins have been established in humans [1-3]. They are the basic protein molecules forming gap junction channels (GJChs). Each GJCh consists of two apposing hemichannels (connexons). Each connexon is composed of six sub-unit proteins called connexin $(\mathrm{Cx})$, various combinations of connexin molecules leading to diverse connexons (either homomeric or heteromeric), and GJChs with different properties [4]. GJChs form transcellular pathways and hemichannels mediate communication between the cellular interior and the extracellular space.

Gap junction channels (GJChs) are important in many biological systems including the nervous system in both neurons and glial cells. GJChs are responsible for metabolic coupling mediated by small molecules such as second messengers (IP3, cAMP, cGMP, and others), diverse metabolites (e.g. glucose, amino acids, glutathione, ATP), neuroprotectants (e.g. adenosine) and ions. The essential role of GJChs in the human cochlea is evident from association between mutational changes and deafness $[5,6]$. Mutations of GJB2, the gene encoding connexin 26, are the most common cause of genetic deafness, and mutations of five other connexins - Cx29, Cx30, Cx31, Cx32 and $\mathrm{Cx} 43$ - have also been linked to either nonsyndromic or syndromic sensorineural hearing loss [7-9].

The human GJA1 gene is located on chromosome $6 \mathrm{q} 14 \rightarrow 24$ [10]. Cx43 encoded by GJA 1 is a protein component of GJCh or hemichannel, omnipresent in brain astrocytes [11-13] and nociceptive sensory ganglion satellite glial cells $[14,15]$. Mutations of GJA1 in relation to nonsyndromic hearing loss were only reported 10 years ago, when two types of $\mathrm{Cx} 43$ mutations, L11F and V24A, were found by Liu et al. [8]. These mutations were later shown to be in the pseudogene of GJA1 ( $p G J A 1)$ on chromosome 5 [16]. Mutations in $p G J A 1$, the pseudogene, as well as in GJA1 have recently been identified by Yang et al. [9] as being causally related to hearing loss.

The expression patterns of connexins, including $\mathrm{Cx} 43$ in the inner ear, have been studied mainly in rodents and the 
Table 1. Antibody characteristics and combinations.

\begin{tabular}{|c|c|c|c|}
\hline Antibodies & Dilutions & Characteristics & Hosts \\
\hline anti-C $\times 43^{*}$, anti-Tubulin ${ }^{\star *}$ & $1: 200,1: 200$ & poly, mono & $R b, M s$ \\
\hline anti- $C \times 43$, anti-MBP§ & $1: 100,1: 100$ & poly, mono & $R b, R t$ \\
\hline anti-S100\$§, anti-Tubulin & $1: 300,1: 200$ & poly, mono & $R b, M s$ \\
\hline
\end{tabular}

mono-monoclonal antibody; poly - polyclonal antibody; $M s$ - mouse; $R b$ - rabbit; $R t$ - rat; ${ }^{\star}$ Zymed; ${ }^{* *}$ Chemicon; §igma; §§ Dako.

results appear inconsistent. The difficulties in human cochlear research lie in the fact that the tiny, delicate hearing organ is deeply located in the skull base and surrounded by a hard bony capsule. By using cochlear specimens obtained from patients being operated on for life-threatening intracranial tumors, we have studied and reported several types of connexin expressed in the human cochlea [17], including a brief presentation of $\mathrm{Cx} 43$ expression in satellite cells of the human spiral ganglion. We subsequently performed Cx43 immunohistochemisty (IHC) on more cochlear sections, and investigated stained sections by using laser scanning confocal microscopy. Here we present the results and discuss the potential roles of $\mathrm{Cx} 43$ in the human cochlea.

\section{Material and methods}

\section{Cochlear fixation and sectioning}

The study is based on 5 human ( 2 male, 3 female, ages 45 to 56) cochleae removed during surgery. The cochleae are from patients with giant petroclival meningioma, a life-threatening condition, and were dissected out during a transcochlear operation. Most of the ears had normal pure tone thresholds before the operation. The threshold values of pure tone audiometry (PTA) in 4 patients were below $15 \mathrm{~dB}$ at each frequency measured. In one patient, at frequencies over $2000 \mathrm{~Hz}$, the threshold values were between $25 \mathrm{~dB}$ and $35 \mathrm{~dB}$. The study was approved by the local ethics committee (no. 99398, 22/9 1999, no. C254/4, no C45/7 2007) and patient consent was obtained.

The cochlea was dissected out and immediately placed in $4 \%$ paraformaldehyde (PFA) dissolved in phosphate buffered saline (PBS; $\mathrm{pH}$ 7.4). At the starting point of the fixation, the cochleae were gently perfused with fixative with a small cannula. After 24 hours fixation, the fixative was replaced with $0.1 \mathrm{M}$ PBS and decalcification of the cochleae was carried out with $0.1 \mathrm{M} \mathrm{Na-EDTA}$ in phosphate buffer at $\mathrm{pH}$ 7.2. Four weeks later the chelate-decalcified cochleae were rinsed with PBS and made ready for sectioning. For frozen sections of the cochleae, they were embedded in Tissue-Tek O.C.T. (Polysciences, Inc., Warrington, PA), rapidly frozen and sectioned in a cryostat at $8-10 \mu \mathrm{m}$. The frozen sections were collected onto gelatin-chrome coated slides and stored below $-70^{\circ} \mathrm{C}$.

\section{Immunohistochemistry}

Antibodies against Cx43, glial cell marker S-100, myelinating glial cell marker myelin basic protein (MBP), and neuron marker Tuj 1 were used for immunohistochemistry of the human cochlear sections; both single and double-staining was done. Table 1 shows combinations, dilutions and source of the antibodies.

Incubation of the sections with mixed antibodies was carried out under the protocol as previously reported [17]. Briefly, sections covered with antibody solution were placed in a atmosphere at $4^{\circ} \mathrm{C}$ for 20 hours. Sections used as negative controls in each experiment were incubated with $2 \%$ bovine serum albumin (BSA) instead of antibodies. After incubation with primary antibodies or BSA, the sections were rinsed with PBS $(3 \times 5$ minutes). Sections were subjected to reaction with Alexa Fluor 488 and 555 (Molecular Probes Inc.) conjugated secondary antibodies (Invitrogen, USA) for 2 hours at room temperature. This was followed by DAPI (4,6-diamidino-2-phenylindole) (Invitrogen, USA; lot no. 474302) counter staining for 5-7 minutes at room temperature. Sections were mounted with Vectashield (Vector Labs). For positive $\mathrm{Cx} 43$ antibody control, frozen sections of guinea pig trigeminal ganglion were obtained using the same methods as used for obtaining human cochlear sections. We used trigeminal ganglion for positive antibody control because Cx43 expression in the nociceptive ganglion of rodent has been reported (trigeminal ganglion, [14]; dorsal root ganglion, [15]).

\section{Confocal, fluorescent and bright-field imaging}

Bright-field images were used to identify the inner ear structures. Fluorescent images were obtained using an inverted fluorescent microscope (Nikon TE2000, Japan) equipped with fluorescence unit and a digital camera with three filters (for emission spectra at 358, 461, and $555 \mathrm{~nm}$ ) and connected to a computer system including imagemerging software. For confocal microscopy we used a Nikon TE2000 microscope equipped with a laser imaging system using three different filters. A computer-based program, EZ-C1, was used for storing images and reconstructing $\mathrm{z}$-stack images into 3-D images. All images were saved as uncompressed JPG files. Single optical section images at $0.1 \mu \mathrm{m}$ rather than their projections were used in this paper.

\section{Results}

For defining various cochlear cell types - e.g. basal cells of the stria vascularis, hair cells and supporting cells of the organ of Corti, spiral neurons and their satellite glial cells in the spiral ganglion - we used morphological, positional and bordering features of these structures observed under both mono-color and bright-field conditions which helped us to precisely identify the structures mentioned in the following description. 


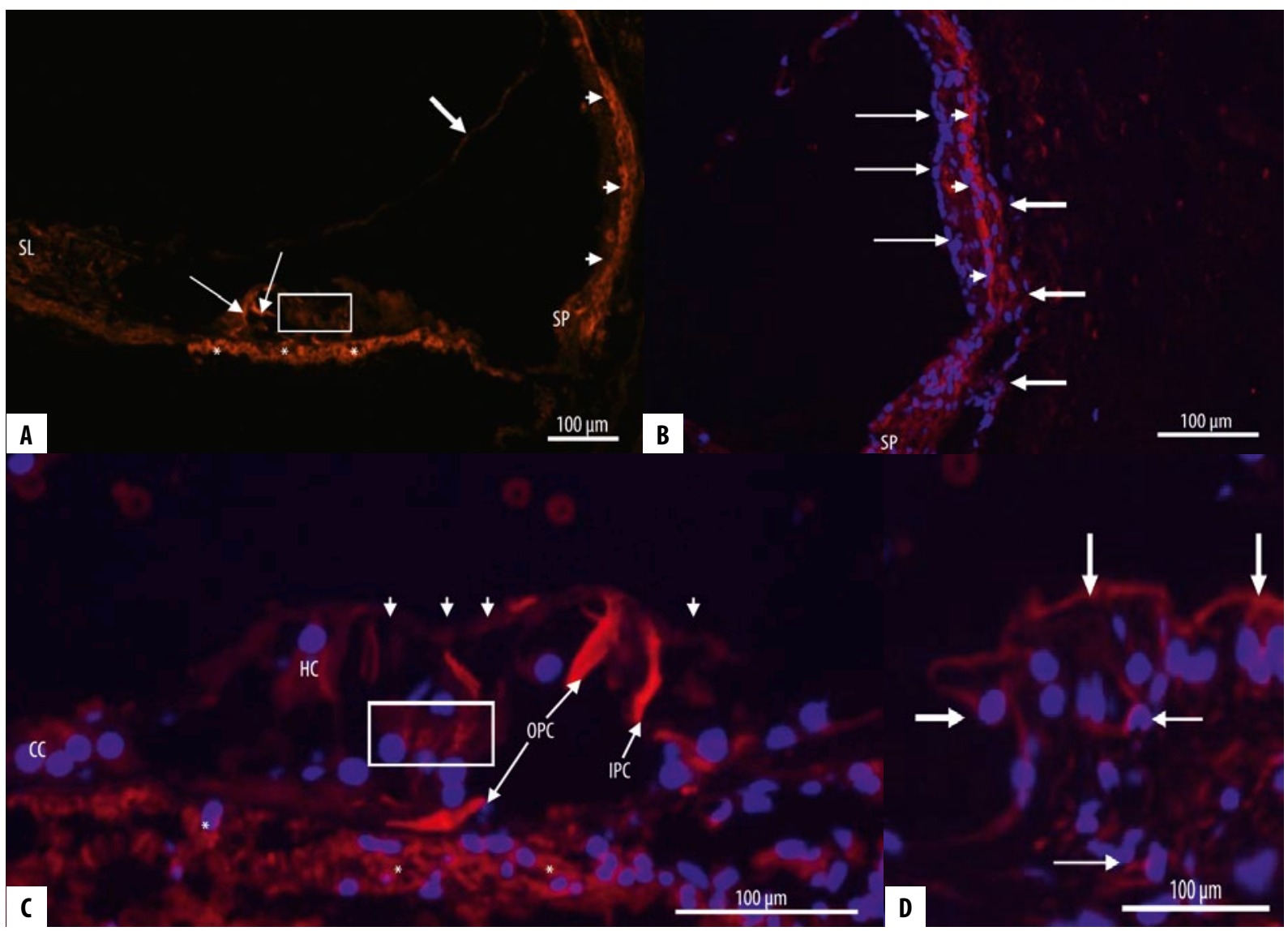

Figure 1. Cx43 immunohistochemistry of the human cochlea. (A) an overview of immunostaining for $\mathrm{Cx} 43$ in a middle turn of the human cochlea. Positively stained structures are indicated as follows: arrowheads, basal cell layer of stria vascularis; thin arrows, pillar cells; asterisks, covering cell layer beneath the basilar membrane; SL, spiral limbus; SP, spiral prominence; square, Deiters cells. Thick arrow indicates vestibular membrane which can be hardly seen due to very weak background labeling. (B) strong Cx43 immunolabeling in the basal cells (arrowheads) of cochlear lateral wall; weak, sparse labeling in the spiral ligament fibrocytes (thick arrows). Marginal cells were not labeled (thin arrows); substantial labeling in spiral prominence (SP). (C) both inner (IPC) and outer pillar cells (OPC), as well as cells in the covering layer (asterisks) beneath the basilar membrane were strongly labeled. Deiters cells (square), Hensen cells (HC) and Claudius cells (CC) were moderately labeled. Inner hair cell (single arrowhead) and outer hair cells (triple arrowheads) were not labeled. (D) structures with weak Cx43 expression in spiral limbus (SL) were indicated with thick arrows (epithelial layer) and thin arrows (fibrocytes).

Expression of $\mathrm{Cx} 43$ in the lateral wall and in the organ of Corti of the human cochlea

To locate the expression of $\mathrm{Cx} 43$ in the human cochlea, the cochleae were carefully obtained during operation and rapidly placed in fixative in the operating room. IHC was performed on $8 \mu \mathrm{m}$ thick cryosections. The immunolabeling was investigated using fluorescent and laser confocal microscopes. Immunolabeling of $\mathrm{Cx} 43$ was confined to several cochlear structures as shown in Figure 1. The lateral wall of the human cochlea showed cumulative positive Cx43 staining at the basal cell layer of the stria vascularis, extending to the spiral prominence, whereas a dispersed distribution was seen in the fibrocytes of the spiral ligament. The marginal cell layer was not labeled by $\mathrm{Cx} 43$ antibody. In the organ of Corti, both inner and outer pillar cells (IPC and OPC), and cells in the covering layer beneath the basilar membrane, were strongly labeled by $\mathrm{Cx} 43$ antibody. Deiters cells and cells in the spiral limbus were also stained.

\section{Expression of $\mathrm{Cx} 43$ in the human spiral ganglion}

To locate $\mathrm{Cx} 43$ immunoreactivity in the spiral ganglion, different cell types were identified using their specific markers. Mainly double immunostaining with a combination of a cell marker antibody and $\mathrm{Cx} 43$ antibody was performed on freshly fixed and carefully sectioned human cochleae. Cx43 antibody labeled satellite glial cells (SGCs) surrounding the spiral neuron cell bodies, while the antibody for myelinating glial cell marker MBP stained the myelin sheath of the nerve fibers (Figure 2). Confocal microscopic images showed that $\mathrm{Cx} 43$ immunoreativity products were punctate and localized in the cytoplasm of the SGCs (Figure 3A) that was not stained with Tuj-1 antibody. At low power, $\mathrm{Cx} 43$ labeling looked continuous rather than punctate and consequently the labeled SGCs were connected with each other forming a network (Figure 3B), similar to the cellular network stained with $\mathrm{S} 100$ antibody in adjacent sections (Figure 3C). S100 immunostaining labeled both SGCs enveloping neuronal cell bodies and Schwann 


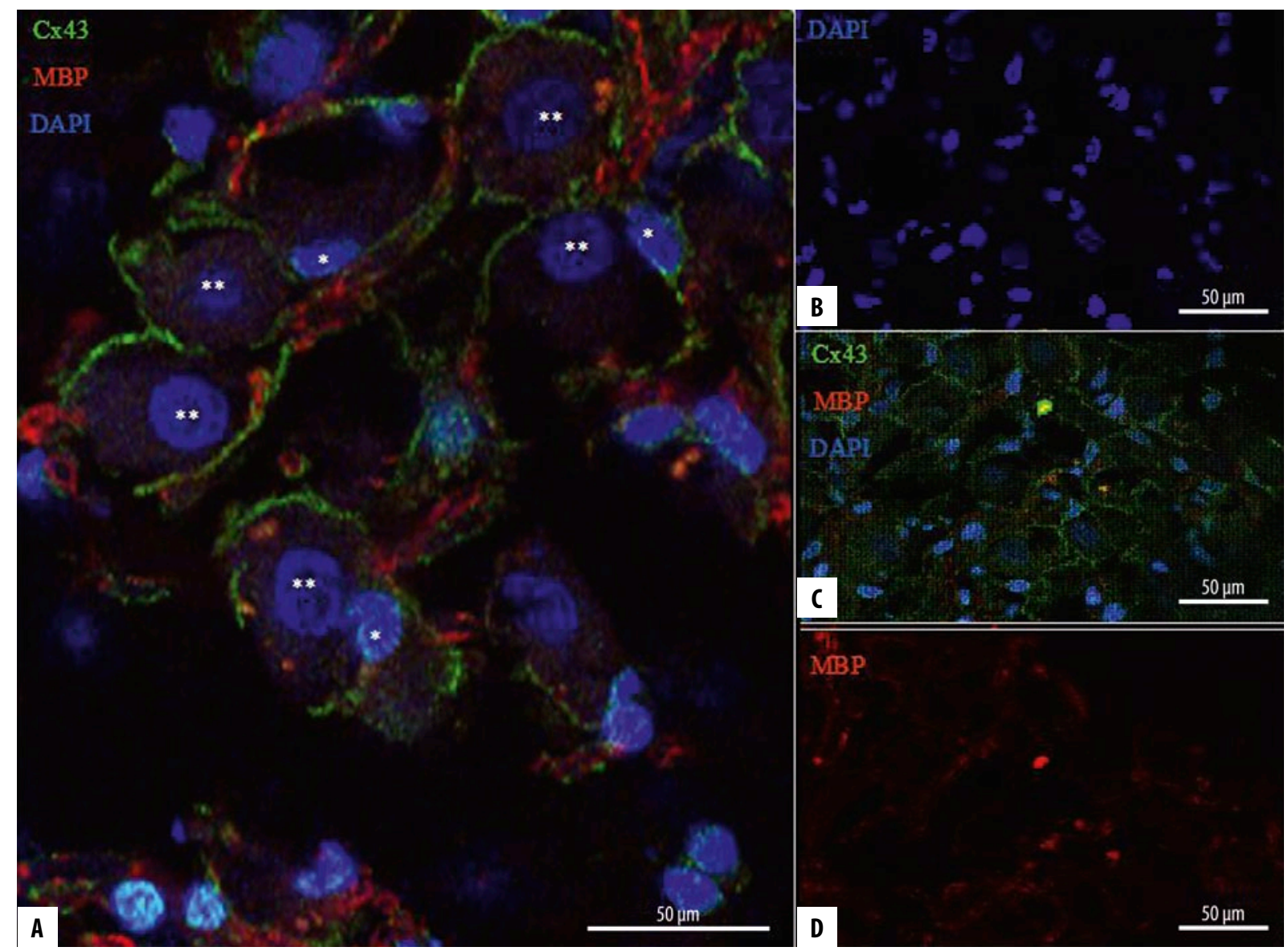

Figure 2. Cx43 immunohistochemistry in the human spiral ganglion. (A) a confocal micrograph showing Cx43 (green) antibody labeled satellite glial cells and myelin basic protein (MBP, red) antibody labeled myelin sheath of the nerve fibers. The smaller, oval nuclei (single asterisk) belonging to satellite glial cells were heavily stained with DAPI whereas the larger, round type I neuron's nuclei (double asterisk) show weaker DAPI stains. The Cx43 labeling can be seen in the peri-nuclear region of SGCS extending to the thin layer of their cytoplasm. Cx43 labeling was mostly separated from MBP labeling. (B, C and D) are low power confocal images from an area adjacent to $A$ at a second turn ganglion showing a totally different pattern of $C \times 43$ and MBP immunostaining, the former staining mainly SGCs but the latter the nerve fiber's myelin sheath.

cells lining the myelinated nerve fibers. The nuclei stained with DAPI served as a means of distinguishing neurons from SGCs, the former having bigger, round and weakly DAPI-stained nuclei, whereas the latter had smaller, oval and strongly DAPI-stained nuclei (Figures 2 and 3).

\section{Negative and positive antibody control}

In the negative antibody control experiments, the primary antibodies were replaced with BSA and they yielded no immunofluorescence in any structures of the cochleae including SG (Figure 4A, B). In the positive antibody control, where $\mathrm{Cx} 43$ immunohistochemistry was done on the sections of guinea pig trigeminal ganglion, punctate staining was seen around the outside of the ganglion neurons labeled with Tuj1 antibody (Figure 4C). The outcome of positive control was consistent with reported results [14,15], suggesting an efficacy of the antibody and IHC protocol.

\section{Discussion}

The specificity of anti-Cx43 antibody used here for human Cx43 has been confirmed by Western blots in which the antibody detected a 43-kDa protein in human smooth muscle cell extracts. Reactivity of this Cx43 antibody with other connexin types had not been observed on Western blots, and this highly specific reactivity is independent of phosphorylation status (www.invitrogen.com).

Only a few studies, mostly in the fetal ear, about connexin distribution in the human inner ear have been performed $[5,18]$ because collecting and processing well-preserved human inner ear tissue remains a challenge due to its rapid deterioration, small volume, delicate nature, and hard bone encasement. We published a study on the expression of several $\mathrm{Cx}$ in well-fixed normal adult human cochleae [17], where Cx43 was, under fluorescent microscopy, expressed in satellite cells enveloping spiral neurons. We subsequently analyzed $\mathrm{Cx} 43$ expression using a confocal immunofluorescence method combined with anitibodies for glial cell marker S-100 and myelin sheath marker $\mathrm{MBP}$ in addition to routine use of Tuj 1 for neurons. Laser scanning confocal microscopy demonstrated immunostaining and cellular structures in more detail than the conventional fluorescent microscopy used in our previous investigation. 


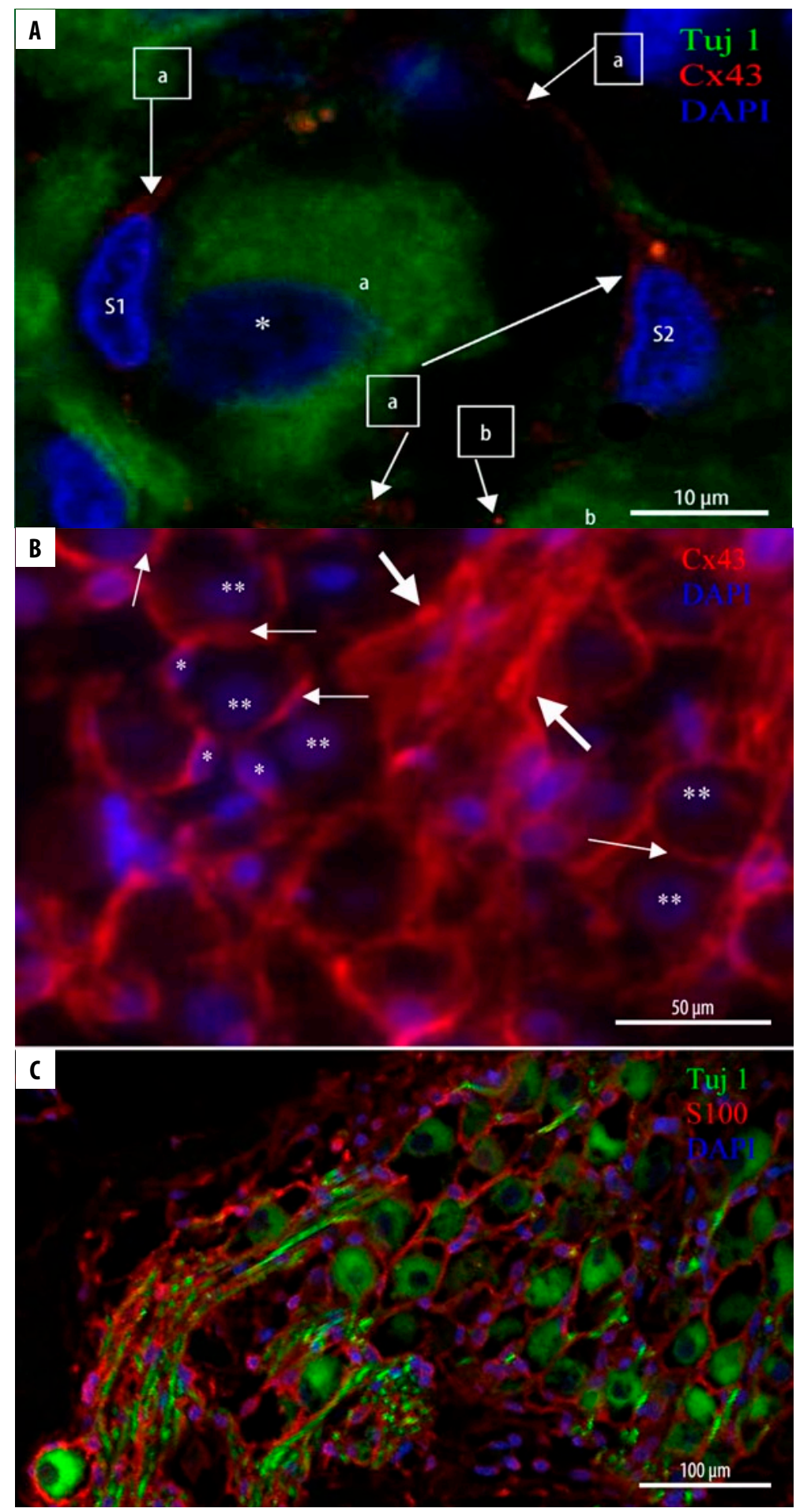

Figure 3. Cx43 immunohistochemistry in the human spiral ganglion. (A) high power laser scanning confocal image demonstrating neurons with their perikarya expressing Tuj-1 (green) and SGCs presenting Cx43 immunostained puncta in the cytoplasm (red, indicated by arrows). These Cx43-expressing SGCs belong to two neurons (a and b). Apparently, the puncta scatters in the whole cytoplasm of SGCs including the peri-nuclear area (S1 and S2 indicate nuclei of SGCs). SGCs have typical oval nuclei that were more strongly stained with DAPI than the nuclei of neurons (asterisk) which have bigger, round nuclei. (B) Cx43 immunostaining (red) looks diffuse under low power fluorescent microscope. The staining is clearly continuous between the peri-nuclear area (nuclei indicated with single asterisks) and the rest of the ring-like thin cytoplasm of SGCs which envelop type I neurons (the neuron's nuclei are indicated with double-asterisk). Thin arrows indicate the cytoplasm where two adjacent satellite cells meet and are tightly connected; thicker arrows point to the nerve bundle that is labeled with Cx43 antibody. The networklike structure formed by $\mathrm{Cx} 43$ positive SGCs fits S100 positive network conformation (C). The photos are from the second turn.

In the analysed human cochleae, $\mathrm{Cx} 43$ was located in the basal cell layer of the stria, in the fibrocytes in the spiral ligament, in the outer and inner pillar cells as well as Deiters cells of the organ of Corti, and in the covering cell layer beneath the basilar membrane. In the spiral ganglion, Cx43 was found in SGCs that were also stained by S-100 but not Tuj 1 antibody. The thin layer of Cx43-positive SGCs are connected, forming a network clearly revealed by S-100 immunostaining which apparently lacked co-staining of MBP. A few previous studies on Cx43 distribution in the inner ear have been performed in rodents and variation of the results could not be explained solely on the basis of species $[8,19,20]$. Connexin 43 was found by Cohen-Salmon and coworkers almost exclusively in the bone of the otic capsule in mature mouse [20]. In adult rat, $\mathrm{Cx} 43$ was found in the basal cell layer, at the lateral side of the spiral ligament in stria vascularis, and in the spiral limbus [19].

We have observed both heteromeric and homomeric type of GJChs composed of Cx26 and Cx30 in the stria vascularis of the human cochlea as well as in supporting cells of 


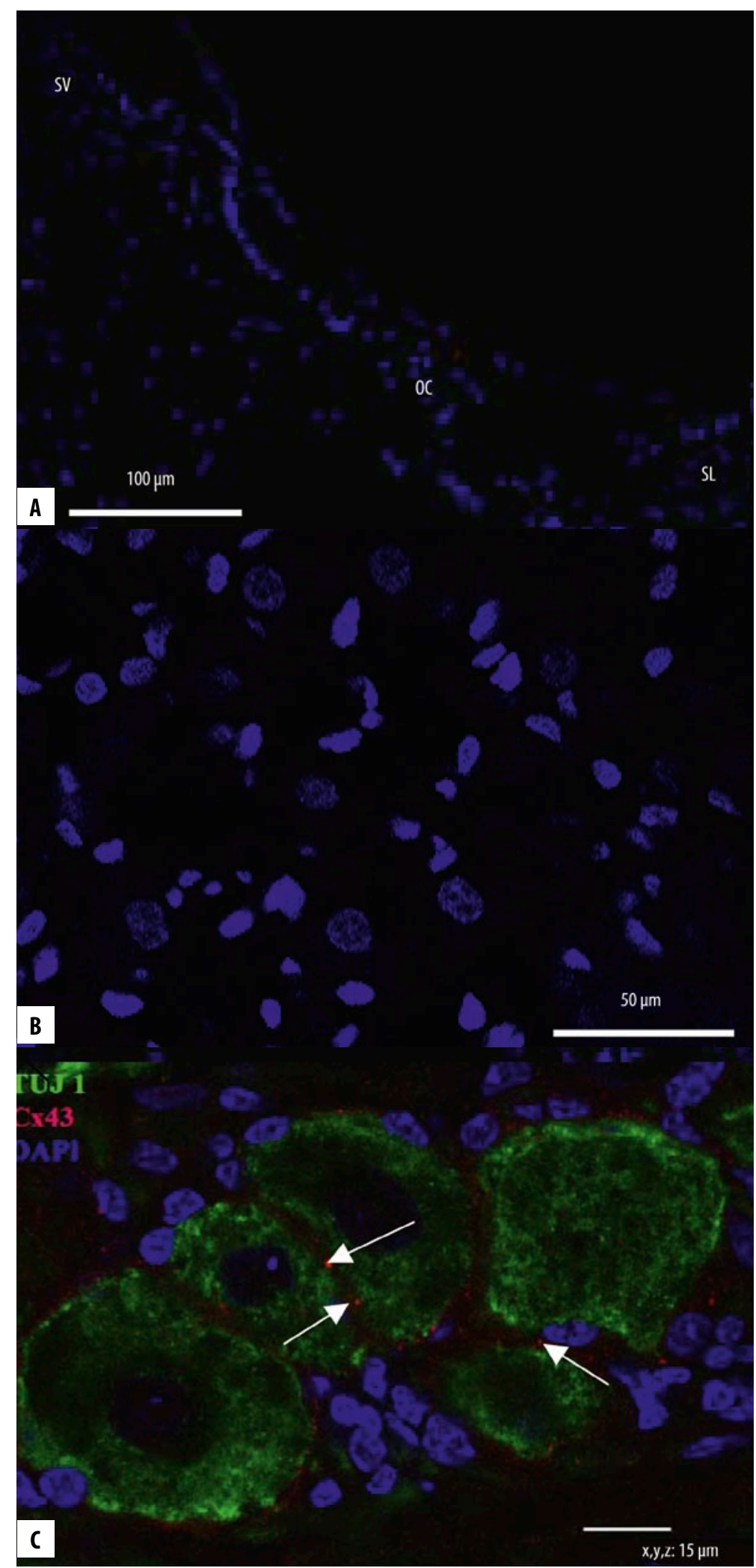

Figure 4. Immunohistochemistry with BSA replacing $\mathrm{Cx} 43$ antibody (negative antibody control) (A and $\mathrm{B}$ ) and $\mathrm{Cx} 43 \mathrm{IHC}$ on the guinea pig trigeminal ganglion section (positive control) (C). In the negative control, the stria vascularis (SV), organ of Corti (OC), spiral limbus (SL) (A) as well as SG (B) had no positive immunostaining. In the positive control, where Cx43/Tuj $1 \mathrm{IHC}$ was carried out on sections of guinea pig trigeminal ganglion, confocal micrograph showed Cx43 immunoreative punctate products (arrows) in SGCs around Tuj 1 positive neurons.

the organ of Corti [17]. In these structures, whether Cx43 co-exists with other connexins, especially $\mathrm{Cx} 26$ or $\mathrm{Cx} 30$, to form heteromeric or heterotypic GJChs needs to be elucidated in future study. In satellite cells, we didn't find Cx26, Cx29, Cx30, Cx32 or Cx36 ([17] and unpublished data). However, the homomeric property of Cx43 GJChs in the satellite cells of the human needs to be proved. It is not surprising that SGCs in human SG do not express MBP since electron microscopy (EM) had demonstrated this type of cell to be unmyelinated $[21,22,23,24,25]$. The functional implication of $\mathrm{Cx} 43$-expression and the unmyelinated nature of human SGCs [26] should not be underestimated. 
GJChs are essential for recirculation of $\mathrm{K}^{+}$ions during hair cell excitation [27] and such a function of the channels in the spiral ligament is associated with endolymphatic potential (EP) maintenance [28]. The high level of potassium produced as a result of spiral neuron excitation in human SG might have to be buffered so as to protect the neurons from potassium toxicity. In addition, recent studies suggest that the role of gap junction channels in the cochlea may not be limited to $\mathrm{K}^{+}$recycling [29]. Cx43-expressing astrocytes in the CNS and SGCs in the spinal and trigeminal ganglion function actively in homeostasis maintainence, neuroprotection and signal regulation. There is evidence of satellite cell-enwrapped spiral neurons in human SG surviving for many years after deafferentation [30].

Procacci et al. [15] found a significantly lowered level of Cx43 expression in perineuronal satellite cells in the spinal ganglion of aged mouse, in accordance with the theory that a prominent decrease in $\mathrm{Cx} 43$ is a marker of senescence [31]. It was earlier reported that reduced expression of $\mathrm{Cx} 43$ in satellite glial cells of the trigeminal ganglion resulted in spontaneous pain behavior [14] Changes of $\mathrm{Cx} 43$ in the human spiral ganglion possibly underlie certain auditory symptoms with unknown mechanisms, including tinnitus and certain forms of sensorineural hearing loss.

Mutations of Cx43 gene GJA1 or its psudogene $p G J A 1$ were causally linked to hereditary sensorineural hearing loss in patients $[8,9]$. $p G J A 1$ is the only $\mathrm{Cx}$ gene family that is a pseudogene and has features of an expressed gene, e.g. translating its sequence into protein. To prove this, Hong and coworkers [32] recently compared the intracellular distribution and assembly of three $\mathrm{Cx} 43$ mutants expressed in HeLa cells with their wild-type (WT) counterparts, and revealed expression as well as effects of the mutant proteins on the cells. Dye transfer assay demonstrated a decreased gap junctional intercellular communication in HeLa cells carrying mutant GJA1 or $p G J A 1$ gene compared to WT-expressing cells, indicating a role of the mutations in the loss of normal functions carried out by $\mathrm{Cx} 43$.
Human spiral ganglion SGCs share morphological and chemical features with their counterparts in rodent nociceptive sensory ganglia (trigeminal and spinal ganglion), e.g. nuclei stained strongly with DAPI, lack of MBP or other myelin markers, and broad connection between their cytoplasm which is rich in S-100 protein [15]. The morphological similarity may not necessarily mean functional similarity, but major morphological differences between satellite glial cells of human SG and the "satellite glial cells" of animal SG motivate care in translating functional data from animal to man. This is significant because an in vitro model for human spiral neuron-satellite cell interaction is still missing.

\section{Conclusions}

Using a confocal immunofluorescence method, Cx43 expression was found in stria vascularis, the organ of Corti and satellite glial cells of the human cochlea. The human cochlear specimens had been obtained from patients undergoing transcochlear surgery for removal of giant intracranial tumors. Prompt fixation of the cochleae is likely to have preserved the antigenicity of the epitopes detected. Differences in distribution of $\mathrm{Cx} 43$ in the human cochlea from the rodent cochlea were observed. Interactions between satellite glial cells where $\mathrm{Cx} 43$ is expressed and spiral neurons need further elucidation. Based on previous studies, the role of $\mathrm{Cx} 43$-formed gap junction channels and hemichannels in the control of environmental ion concentrations around neurons and sensory epithelial cells in the human cochlea is speculated. It is also assumed that the satellite glial cells facilitate spiral neuron preservation, especially under detrimental conditions.

\section{Acknowledgments}

Our research is a part of the European Community $6^{\text {th }}$ Framework Programme on Research, Technological Development and Demonstration (Nanotechnology-based targeted drug delivery; contract number NMP-2004-3.4.1.5-1-1; project acronym NANOEAR).This study was supported by grants from the Tysta Skolan Foundation, the Hearing Research Foundation (HRF), and the Sellanders Foundation.

\section{References:}

1. Sohl G, Willecke K: Gap junctions and the connexin protein family. Cardiovascular Research, 2004; 62: 228-32

2. Kandel ER, Michael VL: Bennett and the cellular study of neural systems at Albert Einstein and Woods Hole. Brain Res, 2000; 32: $3-5$

3. Hormuzdi SG, Filippov MA, Mitropoulou G et al: Electrical synapses: a dynamic signaling system that shapes the activity of neuronal networks. Biochim Biophys Acta, 2004; 1662: 113-37

4. Bennett MV, Zukin RS: Electrical coupling and neuronal synchronization in the mammalian brain. Neuron, 2004; 41: 495-511

5. Kelsell DP, Dunlop J, Stevens HP et al: Connexin 26 mutations in hereditary non-syndromic sensorineural deafness. Nature, 1997; 387: 80-83

6. Cohn ES, Kelley PM: Clinical phenotype and mutations in connexin 26 (DFNB1/GJB2), the most common cause of childhood hearing loss. Am J Med Genet, 1999; 89: 130-36
7. Martínez AD, Acuna R, Figueroa V et al: Gap-Junction Channels Dysfunction in Deafness and Hearing Loss. Aantioxidant \& Redox Signaling, 2009; 11: 309-22

8. Liu XZ, Xia XJ, Adams J et al: Mutations in GJA1 (connexin 43) are associated with non-syndromic autosomal recessive deafness. Hum Mol Genet, 2001; 10: 2945-51

9. Yang JJ, Huang $\mathrm{SH}$, Chou $\mathrm{KH}$ et al: Identification of mutations in members of the connexin gene family as a cause of nonsyndromic deafness in Taiwan. Audiol Neurootol, 2007; 12: 198-208

10. Corcos IA, Meese EU, Loch-Caruso R: Human connexin 43 gene locus, GJA1, sublocalized to band 6q21!q23.2. Cytogenet Cell Genet, 1993; 64: 31-32

11. Houades V, Koulakoff A, Ezan P, Seif I, Giaume C: Gap junction-mediated astrocytic networks in the mouse barrel cortex. J Neurosci, 2008; 28: 5207-17

12. Cotrina ML, Gao Q, Lin JH, Nedergaard M: Expression and function of astrocytic gap junctions in aging. Brain Res, 2001; 901: 55-61 
13. Yamamoto T, Ochalski A, Hertzberg EL, Nagy JI: On the organization of astrocytic gap junctions in rat brain as suggested by LM and EM immunohistochemistry of connexin 43 expression. J Comp Neurol, 1990; 302: 853-83

14. Vit JP, Jasmin L, Bhargava A, Ohara PT: Satellite glial cells in the trigeminal ganglion as a determinant of orofacial neuropathic pain. Neuron Glia Biol, 2006; 2: 247-57

15. Procacci P, Magnaghi V, Pannese E: Perineuronal satellite cells in mouse spinal ganglia express the gap junction protein connexin43 throughout life with decline in old age. Brain Research Bulletin, 2008; 75: 562-69

16. Paznekas WA, Boyadjiev SA, Shapiro RE et al: Connexin 43 (GJA1) mutations cause the pleiotropic phenotype of oculodentodigital dysplasia. Am J Hum Genet, 2003; 72: 408-18

17. Liu W, Boström M, Kinnefors A, Rask-Andersen H. Unique expression of connexins in the human cochlea. Hear Res, 2009; 250: 55-62

18. Kammen-Jolly K, Ichiki H, Scholtz AW et al: Connexin 26 in human fetal development of the inner ear. Hear Res 2001; 160: $15-21$

19. Suzuki T, Takamatsu T, Oyamada M: Expression of gap junction protein connexin 43 in the adult rat cochlea: comparison with connexin26. J Histochem Cytochem, 2003; 51: 903-12

20. Cohen-Salmon M, Maxeiner S, Krüger O et al: Expression of the connexin43- and connexin45-encoding genes in the developing and mature mouse inner ear. Cell Tissue Res, 2004; 316: 15-22

21. Nadol JB Jr: Comparative anatomy of the cochlea and auditory nerve in mammals. Hear Res, 1988; 34: 253-66

22. Nadol JB Jr: Degeneration of cochlear neurons as seen in the spiral ganglion of man. Hear Res, 1990; 49: 141-54
23. Spoendlin H, Schrott A: Quantitative evaluation of the human cochlear nerve. Acta Otolaryngol Suppl, 1990; 470: 61-69

24. Tylstedt S, Kinnefors A, Rask-Andersen H: Neural interaction in the human spiral ganglion: a TEM study. Acta Otolaryngol, 1997; 117: 505-12

25. Glueckert R, Pfaller K, Kinnefors A et al: The human spiral ganglion: new insights into ultrastructure, survival rate and implications for cochlear implants. Audiol Neurootol, 2005; 10: $258-73$

26. Liu W, Boström M, Kinnefors A et al: Expression of myelin basic protein in the human auditory nerve-An immunohistochemical and comparative study. Auris Nasus Larynx, 2011; May 19. Early Online Publication

27. Kikuchi T, Kimura RS, Paul DL, Adams JC: Gap junctions in the rat cochlea: immunohistochemical and ultrastructural analysis. Anat Embryol 1995; 191: 101-18

28. Cohen-Salmon M, Ott T, Michel V et al: Targeted ablation of connexin26 in the inner ear epithelial gap junction network causes hearing impairment and cell death. Curr Biol, 2002; 12: 1106-11

29. Hernandez VH, Bortolozzi M, Pertegato V et al: Unitary permeability of gap junction channels to second messengers measured by FRET microscopy. Nat Methods, 2007; 4: 353-58

30. Linthicum FH Jr, Fayad JN: Spiral ganglion cell loss is unrelated to segmental cochlear sensory system degeneration in humans. Otol Neurotl, 2009; 30: 418-22

31. Statuto M, Bianchi C, Perego R, Monte UD: Drop of connexin 43 in replicative senescence of human fibroblasts HEL-299 as a possible biomarker of senescence. Exp Gerontol, 2002; 37: $1113-20$

32. Hong HM, Yang JJ, Shieh JQ et al: Novel mutations in the connexin43 (GJA1) and GJA1 pseudogene may contribute to nonsyndromic hearing loss. Hum Genet, 2010; 127: 545-51 